This article was downloaded by: [Dublin City University]

On: 29 J uly 2013, At: 01:35

Publisher: Routledge

Informa Ltd Registered in England and Wales Registered Number: 1072954 Registered office: Mortimer House, 37-41 Mortimer Street, London W1T 3J H, UK

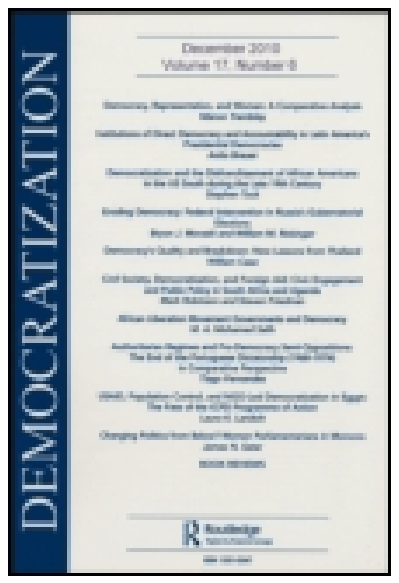

\title{
Democratization
}

Publication details, including instructions for authors and subscription information:

http:/ / www. tandfonline.com/loi/ fdem20

\section{Moderation through exclusion? The journey of the Tunisian Ennahda from fundamentalist to conservative party}

Francesco Cavatorta ${ }^{a} \&$ Fabio Merone ${ }^{b}$

a School of Law and Government, Dublin City University, Dublin, Ireland

${ }^{\mathrm{b}}$ Gerda Henkel Foundation, Düsseldorf, Germany Published online: $25 \mathrm{~J} \mathrm{ul} 2013$.

To cite this article: Francesco Cavatorta \& Fabio Merone (2013) Moderation through exclusion? The journey of the Tunisian Ennahda from fundamentalist to conservative party, Democratization, 20:5, 857-875, DOI: 10.1080/ 13510347.2013.801255

To link to this article: http:/ / dx. doi.org/ 10.1080/ 13510347.2013.801255

\section{PLEASE SCROLL DOWN FOR ARTICLE}

Taylor \& Francis makes every effort to ensure the accuracy of all the information (the "Content") contained in the publications on our platform. However, Taylor \& Francis, our agents, and our licensors make no representations or warranties whatsoever as to the accuracy, completeness, or suitability for any purpose of the Content. Any opinions and views expressed in this publication are the opinions and views of the authors, and are not the views of or endorsed by Taylor \& Francis. The accuracy of the Content should not be relied upon and should be independently verified with primary sources of information. Taylor and Francis shall not be liable for any losses, actions, claims, proceedings, demands, costs, expenses, damages, and other liabilities whatsoever or howsoever caused arising directly or indirectly in connection with, in relation to or arising out of the use of the Content.

This article may be used for research, teaching, and private study purposes. Any substantial or systematic reproduction, redistribution, reselling, loan, sub- 
licensing, systematic supply, or distribution in any form to anyone is expressly forbidden. Terms \& Conditions of access and use can be found at http:// www.tandfonline.com/page/terms-and-conditions 


\title{
Moderation through exclusion? The journey of the Tunisian Ennahda from fundamentalist to conservative party
}

\author{
Francesco Cavatorta $^{\mathrm{a} *}$ and Fabio Merone ${ }^{\mathrm{b}}$ \\ ${ }^{a}$ School of Law and Government, Dublin City University, Dublin, Ireland; ${ }^{b}$ Gerda Henkel \\ Foundation, Düsseldorf, Germany
}

(Received 28 March 2012; final version received 22 April 2013)

\begin{abstract}
The success of processes of democratic change is often predicated on the moderation of anti-systemic and extremist parties. The literature on such parties argues that such moderation, namely the acceptance of democratic procedures, human rights, and a market economy, comes about through inclusion. This seems to be borne out when one analyses a number of Islamist parties having contributed to the progressive democratization of their respective countries. The Tunisian case, however, offers a different perspective on moderation. This article argues that it has been exclusion through repression and social marginalization that has led the Islamist party Ennahda to move from its extreme anti-systemic position of the 1970s to become the mainstream conservative party it is today.
\end{abstract}

Keywords: moderation; repression; exclusion; Ennahda; Tunisia; democratization

\section{Introduction}

On 23 October 2011, the Tunisian Islamist party Ennahda (Renaissance Party) completed a most remarkable comeback on the country's political scene. After having been banned and heavily repressed for three decades with its leaders and cadres either in exile, in prison, or marginalized in society, the party was legalized on 1 March 2011 following the fall of the dictatorship and proceeded to win the first and free elections the country ever held with an impressive score, taking 89 seats out of 217 in the Constituent Assembly. ${ }^{1}$ The victory, or at least the size of it, was a surprise for many Tunisians and for the international community. After the elections Ennahda went on to form a three-party coalition government with two centre-left parties whose ideological references are far removed from its own, highlighting what Ozzano, in his contribution to the special issue, considers an important trait of conservative parties. ${ }^{2}$ Both the party's electoral victory and its decision to form cross-ideological alliances should not be interpreted as surprises. A closer analysis reveals in fact that Ennahda has gone through a profound ideological transformation over its forty-year history that no longer makes it anti-democratic;

*Corresponding author. Email: francesco.cavatorta@dcu.ie 
quite the opposite. ${ }^{3}$ These moderate stances might not be genuine or fully internalized and are certainly not accepted in many left-wing and secular circles: in particular after the assassination of the left-wing leader Chokri Belaid in February 2013, when Ennahda was accused of betraying the revolution and working for the construction of an authoritarian theocracy. ${ }^{4}$ However, what Ennahda has done over the last few years strongly indicates change. In any case, and despite what a number of Tunisian commentators argue when pointing at "its doublespeak", Ennahda can be said to have become what Luca Ozzano categorizes in his framing contribution to this special issue as a conservative party. ${ }^{6}$

In his contribution, Ozzano also claims the categories of religiously oriented parties that he proposes are far from being watertight: parties therefore can move back and forth through these different categories. Accounting for the possibility of change and explaining how this comes about is an important part of the story of many such parties in the Arab world, where the liberalizing trends following the Arab Spring are affording them the opportunity to win power through the ballot box. ${ }^{7}$ Focusing on the case of the Islamist Ennahda, this article examines the mechanisms that explain how a religiously oriented party "travels" from one category to another and the influence this has on the democratization of Tunisia. Specifically, it analyses the very dramatic change that Ennahda made from fundamentalist to conservative party during its existence. From being an anti-democratic and illiberal movement with a tawhid-based (principle of unity) vision of politics and society determined to impose religious law over democratic electoral decisions in the 1970s, it has travelled towards the acceptance of the procedural mechanisms of democracy in the context of a pluralistic vision of society by the late 1980s. The literature on Islamist parties and extremist parties more broadly defines this shift as moderation, whereby the term is synonymous with acceptance of the triptych of democracy - mechanisms to select governing elites, fundamental liberal rights, and market economy. The principal variable to explain this shift can be resumed in "moderation through inclusion", whereby the progressive inclusion of radical and anti-systemic parties into the political system forces them to "compromise" with their original extreme views in order to be able to compete in a pluralistic environment where shared rules have to be designed and where the constraints of participation inevitably force a review of strict ideological positions to attain at least some of the political goals the party has. ${ }^{8}$ In authoritarian settings this is accompanied by the realization that cross-ideological alliances with other opposition parties are also necessary to defeat incumbents.

What is interesting in the case of Ennahda, contrary for instance to the full or partial inclusion of Islamist parties elsewhere, ${ }^{9}$ is that inclusion into the political system never really occurred and acceptance of the party from large sectors of Tunisian society materialized very slowly. Thus, moderation through inclusion does not really explain the very significant change in Ennahda's ideological and political positions and this speaks to the take on moderation that Christophe Jaffrelot has in his article in this special issue. ${ }^{10}$ It follows that a different explanation is required and the article explores what can be labelled "moderation through 
exclusion". For the majority of the literature exclusion is synonymous with the repressive violence that the state perpetrates against opposition political movements and strictness of rules imposed on those wishing to be involved in the political system. ${ }^{11}$ The Tunisian case certainly reflects this type of exclusion against Ennahda - and its previous incarnations as Jamaa and Mouvement Tendence Islamique (MTI). In the early 1990s the state heavily repressed Islamism in the name of safeguarding the country from an obscurantiste ideology and then from 2001 onwards repression was conducted in the name of fighting terrorism. However exclusion can be also defined more broadly to include the social rejection of political projects that are perceived to be alien to mainstream society, which can reinforce and to a certain extent underpin and legitimize state's repression. The hypothesis here is that the harsh repression against the party at the hands of the state, the imprisonment or exile of its leaders and cadres together with the strong rejection the party faced in large sectors of Tunisian society for quite some time made it possible and necessary for Ennahda to entirely re-elaborate how political Islam could contribute to the developmental trajectory of the country. From this reelaboration flows the acceptance of the dominant discourse of democracy, liberalism, and market economy without which the party would not have been able to find much space in Tunisia. Ultimately it is about maintaining religious values simply as references and not as guiding principles of public policy-making, as Olivier Roy also recently pointed out. ${ }^{12}$ Building on this thesis of "moderation through exclusion", the article offers an analysis of the intellectual-ideological introspection that Ennahda went through to be able to find acceptance in the institutional game and, crucially, in wider society. This analysis is based on the examination of the scholarly literature on the party and interviews with many of its leaders.

While it is always difficult to derive generalizations from a single case, the journey of Ennahda can point to significant trends within political Islam and its party expressions at a time when processes of democratization are taking place in the Arab world, albeit amidst considerable difficulties. The linkage between the religiosity of political actors and democratization is usually problematic because such actors are often perceived to be inimical to many fundamental liberal rights and because of their ideological rigidity. The case of Ennahda provides evidence that this might not necessarily always be the case and that democratization can benefit from the positive input of religiously oriented parties.

\section{Ennahda ... in moderation}

In post-revolutionary Tunisia, Ennahda plays a central role in the process of democratization having committed its considerable resources to the construction of a new plural democratic political system that would respect civil liberties and human rights. ${ }^{13}$ This political positioning of Ennahda has come under criticism from some sectors of secular civil and political societies such as women's rights organizations, parties of the extreme left and the new political formation of Bourguibist inspiration Nida Tounes that perceive in the embracing of democracy 
on the part of Ennahda some sort of ruse to obtain uncontested power and then proceed to implement the construction of an exclusionary religion-based state. ${ }^{14}$ In many ways contemporary criticism of and accusations against Ennahda resemble the traditional ones that secular Arabs, or seculars tout court as the introduction to the special issue makes clear, held against Islamist parties since their inception, although in the Tunisian case this criticism is no longer as widespread as it was in the past, as the alliance between Islamists and secular and socialist figures such as Moncef Marzouki and Mustapha Ben Jaafer indicates. In any case, this normative view opens an endless and rather trite debate about the genuine commitment of Islamist parties when it comes to the procedures of democracy and human rights. ${ }^{15}$ This article does not intend to second-guess Ennahda and its actions, preferring instead to focus on its political praxis. Much like in Alaya Allani's work on Ennahda, there is the acceptance that the party has come a long way since its foundation in terms of its attitude towards the fundamental principles of electoral democracy and basic human rights. ${ }^{16}$

When one attempts to trace the political positions of the party over time with respect to the institutional system, economic choices, and social set-up, what emerges suggests a profound shift towards moderation. When looking at Ennahda, its political trajectory is inevitably intertwined with Ghannouchi's intellectual history and the way in which his understanding of the role of Islamism in politics evolved. ${ }^{17}$ Thus, there is no doubt that the party is very much influenced by the development of Ghannouchi's political thinking. However, it would be erroneous to conflate the trajectory of the party entirely with Ghannounchi because other leaders such Abdelfattah Mourou or Mohammed Khouja have also been important activists and thinkers. The outcome of the development of Ghannouchi's thinking, together with the internal debate between different factions within the party - such as the moderate wing of Mourou or the more radical one linked to Salafism that Khouja (the current leader of the Salafist party Front of Reform) embodied - has been one of increasing moderation. There are a number of aspects that seem to confirm such moderation.

First, on the issue of the nature of the Tunisian state, there has been a seachange in the Islamist movement's position since the 1970s. Under the influence of the more militant ideology of the Muslim Brothers of the late 1960s and throughout the 1970s, the movement Rachid Ghannouchi ${ }^{18}$ led subscribed to the creation of an Islamic state whereby the application of sharia law for the whole society reflected the unitary vision embodied in the principle of tawhid. In this vision, there is a perfect and unquestioned overlap between the state and religion. This principle of unity influenced a Manichean view of society and politics whereby "belief" should replace "unbelief": this simple shift would eventually heal all the social and political conflicts in society.

By the early 1980s Ghannouchi had begun to think about the nature of the state in a different manner and the party progressively abandoned this vision. This did not occur seamlessly, as the party went through a significant split in the late 1980s, when a radical fringe left Ennahda to remain on a more uncompromising 
position related to the necessity of building an Islamic state. The party has arrived at a point where it currently supports the creation of a "civil" state (dawla madaniyya), openly subscribing to the idea that references to religion are purely identity-based and not sources for public policy-making. ${ }^{19}$ Thus, in the debate over the drafting of the post-revolutionary Tunisian constitution, the party has been able to compromise with the secular sectors of society on a provision that reflects this principle. This has a practical impact on the strategy of alliances that Ennahda undertakes with some secular parties, refusing implicitly to be the sole representative of the people by virtue of its religious references. ${ }^{20}$ In addition, party leaders emphasize that subscription to democratic procedures and values characterizes the party internally as well. Ali Larayedh, member of the Executive Committee of the party and now Prime Minister, stated that democratic decision-making informs the party at all levels. ${ }^{21}$ This issue of internal democracy is obviously disputed and might not correspond to the reality, but what is interesting to note is that prominent Ennahda leaders feel they have to employ pro-democracy rhetoric to appear as legitimate interlocutors. This profoundly contrasts with Tunisian Salafists for instance, who instead have no qualms about condemning liberal-democracy. ${ }^{22}$

Second, on the issues of fundamental human rights and equality we also witness a profound shift from the early 1970s onwards. This is the continuation of the re-elaboration of the principle of tawhid in so far as imposition of mores of behaviour is justified within the framework of that principle, but once this is transformed into support for a civil state, a different understanding of human rights flows. This is most notable on women's rights and, specifically in the case of Tunisia, on the egalitarian Personal Status Code introduced by Bourguiba in 1956. Despite the virulent opposition that Ennahda still engenders in secular feminist movements such as Femmes Democrates because of its conservative positions on gender relations, the party claims that it fully accepted the liberal Personal Status Code in the 1980s. As mentioned, this does not mean that the party has abandoned its socially conservative views about the role of women in society and about gender relations more generally, which should be centred on the absolute primary role of the family in society. Of course, such acceptance might have been purely instrumental and tactical in order to benefit from the inclusion into the very brief liberalizing period of late 1980s, but the point is that Ennahda did not go back on it when repression hit the movement and when a more radical attitude could have been expected given that there were no benefits to be gained by this position of tactical moderation.

Third, and in line with other Islamist movements, Ennahda started off with little interest for economic matters to develop a critical attitude towards capitalism, particularly in the aftermath of the Iranian revolution through the influence of Ali Shariati, as recognized by Ghannouchi himself. ${ }^{23}$ Ill at ease with socialism as well, the party searched for a third way between the market economy of the imperialist West and the command economy of socialist countries. However, it can be argued that the critique of capitalism dominated the economic agenda of the party during the 1970 s and 1980 s. Thanks to the intellectual input of the 
Iranian revolution in 1979, the leadership was able to make the connection between the promotion of the material interests of the disenfranchized and religious principles, proposing the establishment of an economic model that would eliminate the shortcomings - read profound inequalities - of the capitalist system. While the party maintains in some ways that this third way is still potentially pursuable, ${ }^{24}$ it is quite evident that it has moved significantly towards the acceptance of a market economy integrated into the global neoliberal system as the only way for Tunisia to develop. There has been for instance no real debate about the free trade agreement that links Tunisia so closely to the European economies and even though the party seeks to attract more Gulf investment into the country, the neoliberal logic is the same given that the Gulf economies are fully part of the process of neoliberal globalization. It is revelatory that today the constituency of reference of Ennahda is largely composed of merchants, traders, and business people rather than the fully disenfranchized (mouhammishin) who find instead representation in the extra-institutional Salafist movements or in marginal leftist groups. ${ }^{25}$

Finally, the anti-imperialist dimension of Islamism has been over time considerably diluted. Although there is nominal support for the Palestinians as there was indignation for the 1991 and 2003 invasions of Iraq and therefore a degree of anti-Americanism, these attitudes are widely shared among Tunisian political parties of all ideological persuasions. Currently, the party displays a significant degree of pragmatism on foreign policy matters and has for instance acceded to American demands for a crackdown of Salafist activism in the aftermath of the attack on the US embassy in Tunis in September 2012. Ghannouchi and other leaders have been very reassuring with the United States and the European Union about their intentions on foreign policy matters when it comes to US and European interests in the region. There is a sense that the policies Tunisia pursued in this respect under Ben Ali will not be much altered. ${ }^{26}$

As one can therefore note, the journey towards moderation the party has travelled since the 1970s until its arrival in power in 2011 has been quite a long one. It is a journey towards moderation in so far as it accepts the dominant values and discourses that the majority of the international community subscribes to. Thus, following the two dimensions that Ozzano offers to categorize religiously oriented parties, Ennahda, certainly under the impulse of its leader, changed both ideologically and practically. The question though remains as to what made the party undertake this journey.

\section{The inclusion-moderation hypothesis}

Islamist parties have been central to academic and policy debates of Arab politics since their forceful emergence in the 1970s. More specifically their presence has affected debates about democratization and authoritarian resilience in the region. More often than not the religious orientation of such parties was held to be an insurmountable obstacle to the demise of authoritarian rule, preventing processes of 
tentative democratization from succeeding. ${ }^{27}$ In the 2000 s, the debate on Islamist parties changed because it became noticeable that, increasingly, a number of such movements had begun to adopt and subscribe to the language of democracy and human rights, taking part in participatory politics whenever the opportunity arose. ${ }^{28}$ Over time and despite the scepticism surrounding them both domestically and internationally, a number of them progressively shifted their most radical positions in order to be able to construct cross-ideological agreements with nonIslamist opposition forces with a view to becoming an alternative bloc to the ruling coalition. ${ }^{29}$ Crucially, they also tended to accept invitations to participate in regime-sponsored initiatives of limited political openings despite the realization that such openings would not lead to policy-making power. The literature examining these shifts follows largely the incipit of Olivier Roy's 1992 work in which he pointed to the failure of political Islam as an ideological project alternative to the dominant values of liberal-democracy, suggesting implicitly that Islamism would have to find and elaborate new categories of thinking and action if it wished to remain a relevant political actor. ${ }^{30}$

Given that the dominant international discourse of political legitimization since the end of the 1980s across the globe rested on the three pillars of representative democracy, liberal human rights, and market economy, many Islamist parties began to utilize such categories, although through an indigenous re-elaboration based on the scriptures and interpretations of Islam. While this was occurring, a narrative developed through which mainstream Islamist parties began to be examined according to the notion of progressive moderation ${ }^{31}$ with a focus on the different ways in which such moderation was understood. ${ }^{32}$ This followed the findings of the inclusion-moderation theory as applied in Europe to extreme left-wing parties and religious parties in the aftermath of World War II. Post-World War II societies in Western Europe were more inclusive than the authoritarian regimes in which Islamist parties operated, but Arab regimes have been experimenting with liberalization for quite some time and therefore the literature has attempted to use the hypothesis of moderation through inclusion in such contexts as well. The principal idea of this line of inquiry is derived from the assumption that increased political participation in consensual institutions, whether with the regime or with other opposition parties, leads to the moderation of the Islamist position regarding the nature of the state and the extent of liberal rights. Thus, through continued interaction with other political actors, Islamists learn to moderate and they are socialized into the mechanisms of compromise and bargaining, the very foundation of the liberal-democratic game. ${ }^{33}$ Within this larger literature, two types of studies can be distinguished. On the one hand, we have analyses explaining the "progressive moderation" of specific Islamist parties such as the Turkish Adalet ve Kalkinma Partisi (AKP) or the Moroccan Party for Justice and Development (PJD). They have come to embody the very notion of political moderation and acceptance of democracy and human rights together with a market-oriented stance on economic matters and a pragmatic one on sensitive strategic issues of importance for the West. ${ }^{34}$ On the other hand, there are studies that highlight the 
similarities of the Islamist journey towards moderation with the one that other extremist radical anti-systemic parties travelled in the past, such as the communist parties of Western Europe. ${ }^{35}$

The moderation through inclusion thesis has a number of advantages. First, it contributes to providing the theoretical tools necessary to explain the choice of moderation that many Islamist parties did indeed make given that inclusion and cross-ideological alliances have been a trait of Arab politics in a number of countries over recent years. There are a number of cases where progressive inclusion, no matter how stop-start and limited in nature, did indeed allow Islamist parties to come to accept ideological compromises and endorse pragmatism in order to participate, at times marginally and at others more substantively, in political life. Second, it has the merit of challenging, from a policy-making perspective, the validity of the choice of relentless repression of political expressions based on religious prescriptions. Finally, it has the benefit of "normalizing" Islamist parties and their attitudes on a range of issues because it provides a parallel with other contexts and ideologies that demonstrate how the Arab world might not be so "exceptional" in terms of its apparently culture-specific rejection of democracy and human rights.

However, the "moderation through inclusion" thesis has a significant shortcoming, which undermines in part its applicability and validity across all cases. Crucially, there is very little thinking about the possibility that exclusion might have led anti-systemic parties to revise their ideological tenets and political strategies towards moderation in cases where there was no inclusion to speak of. There is a rather widespread assumption that repression of anti-systemic views provokes further radicalization and ultimately anti-systemic violence as a reaction. A number of studies highlight how it is the violent repression of the state that is responsible for radicalization, which, in turn, prevents not only moderation but also democratic political change. ${ }^{36}$ However there is, at least in theory, the possibility that the vast majority of those who are repressed and rejected in large sectors of society might end up critically revisiting their activism. Thus, rather than opting for radicalization, they might instead choose to re-formulate the ideological tenets and strategies that brought about repression and social rejection to moderate their stances and demands. While this might certainly not hold true for the whole of the movement or party being targeted for repression - with the outcome of creating splits - it might be true for a sufficient number of leaders and cadres to see that their radicalism has failed to make headway, leading them to think about ideological and concrete changes. It is this aspect of moderation through exclusion that the following section explores, with a focus on the Tunisian case. It is always problematic to generalize from one case study, but the conditions that led to the moderation in the Tunisian case can potentially be present in other Arab societies.

The case of Ennahda is interesting precisely because the dominant narrative of moderation through inclusion does not apply given the almost relentless state repression and widespread social rejection it faced over the last four decades. Despite exclusion, the party has certainly moderated more than sufficiently for 
key actors on both the Tunisian and international stages to deserve to be treated as possibly the most moderate and pragmatic Islamist party in the Arab world. ${ }^{37}$

\section{Ennahda's long march}

As mentioned earlier, a number of cases such as the Turkish AKP or the Moroccan PJD or the Yemeni Islah confirm the validity of the moderation by inclusion thesis whereby there is a strict correlation between the progressive institutionalization of Islamist parties and their acceptance of democratic constraints. The Tunisian case offers a rather different perspective on the mechanisms of moderation. Having established that the Islamist movement in Tunisia came a long way, inclusion and progressive institutionalization in the political system cannot be said to have been the principal explanatory variables; quite the opposite is true. In fact the Tunisian specificity is that the Islamist movement faced a double exclusion: from the state and from large sectors of Tunisian society. It is at this juncture where the novelty of this analysis resides in so far as we tease out the meaning of exclusion to make it a more fluid concept than simply state-led repression. On the one hand was the traditional type of exclusion linked to state repression and specifically the outright refusal to integrate any religious movement into the political system. This type of exclusion was quite relentless throughout the dictatorships of both Bourguiba and Ben Ali, although there were a couple of very small openings during the 1980s. ${ }^{38}$ This exclusion brought down significant violence on the Islamist movement with its leaders and ordinary members periodically arrested, imprisoned for long periods, or exiled. On the other hand there is the exclusion of the Islamists coming from society, particularly in the 1970s, 1980s and, although less intense, into the 1990s. Tunisian understanding and practice of Islam was certainly a value of reference for many ordinary citizens, but they perceived it quite apolitically. It follows that the politicization of religion that Islamists brought to the fore was largely alien to their political and social vision and struggles. Rachid Ghannouchi also recognizes this when he talks about the place that Islamism had in Tunisia in the 1970s: "Islamist militants felt a sense of alienation from wider society ${ }^{\prime 39}$ because they sensed rejection and not only because they were dissatisfied with the place of religion in Tunisia.

The analysis of the evolution of the Tunisian Islamist movement from fundamentalist to conservative has to take into account both types of exclusion as explanatory mechanisms for the re-elaboration of the theoretical and ideological underpinnings of the Islamist project in the country, away from the rigidity of an Islamic state imposed from the top to the acceptance of a plural civil state. What we have is a dialectic mechanism whereby the movement initially - and the structured party later - has to change from within because of the conditioning from without. In some ways the mechanisms of exclusion catalyzed some of the internal ideological debates that were naturally occurring in a heterogeneous movement. Particularly, the focus should be on the impact of the mainstream ideological and cultural vision of society, referring to the understanding and acceptance of 
categories of modernity embedded in the Tunisian national consciousness. These are embodied in a tradition of tolerance and religious reformism of the scholars of the Zitouna. In short, according to Sami Brahim, a leading Islamic intellectual, ${ }^{40}$ Tunisia is characterized by the predominance of what he calls "an implicit social consensus", whereby extremisms, including religious ones, are largely rejected in society. This means that forms of social organization that do not fall within this consensus remain marginal and minoritarian. Brahim gives the example of polygamy, a practice perceived to be illiberal and anti-women, to illustrate this point in the sense that Tunisian society has integrated, across its social milieux, the refusal of such practice, although this is permitted in the literalist understanding of the scriptures. This refusal generates a political consensus that includes the vast majority of Islamism. The main argument is really about Tunisian society as a natural limit to extremism, which is a point that comes across in discussions with younger members of Ennahda as well. For instance, they do not genuinely understand radical Salafist literalist positions and perceive them as alien. ${ }^{41}$

If one traces the history of the movement back to its early jamaa stage and its later incarnation as a political party, it is possible to detect change towards moderation not as the product of inclusion but of conflict with a society that used to reject Islamism and embraced it only when it became fully "Tunisian". The first real encounter with wider Tunisian society and its attitudes took place on university campuses in the 1970s. Until then the jamaa was concerned with the organization of discussion "circles" (halaqat) in mosques and schools where a type of Islamism anchored in the readings and experiences of the Qutb-inspired Egyptian Brotherhood dominated. Within this context, there were in the jamaa simplistic beliefs and assumptions of how Islam could be politically activated in society, according to Ghannouchi. ${ }^{42}$ The categories through which they operated had to do with the conflict between "belief" and "un-belief" that they perceived in Tunisian society. Once Islamist students began to be active on university campuses, they realized quite quickly that the left dominated the political scene and that, more broadly, social mores were heavily secularized. Islamism was therefore seen as somewhat alien among the activist youth and in both working-class and bourgeois circles, not because the religious practices were alien to ordinary Tunisians, but because the problems and issues that society faced as a whole could not be solved and even conceived of in the simplistic categories of belief and unbelief. In addition, all this was occurring at a time when the Bourguibist secular political project was the state's ideology, which the Islamists were also up against. Among Islamist students, there was the sudden realization that they had very little or nothing to contribute to the national debate about the direction Tunisia should take economically, socially, and politically, because for a long time the categories used for such debate were framed through secular ideologies. This came as a shock to many of them and in this phase it is important to underline that their lack of success and sense of alienation were not the product of repressive exclusion, because state authorities were actually quite tolerant of their activism on campuses; it came about because of societal exclusion. The socialist and Marxist left occupied almost entirely the 
public space in universities - and was able to mobilize the youth because it seemed to be the only political project alternative to Bourguiba's. It was, however, just as secular as Bourguibism. Islamist students on campuses had intense debates with leftist students, which the left won hands down in so far as it became the protagonist of the 1978 general strike on the part of the trade union Union Générale Travailleurs Tunisiens (UGTT) against Bourguiba. ${ }^{43}$ This was a turning point for the Islamists because they were faced with the irrelevance of their categories among those who opposed the regime in place. While they still thought in terms of belief and unbelief, society was either on a leftist revolutionary path or behind the secular Bourguiba. Thus, Islamists had to decide whether they wanted to go back to their discussion circles and become marginalized or change direction to be appealing to the politicized masses entering the scene against the regime. ${ }^{44}$ In short, the limits of social representation of the Jamaa at this stage lay with the inability to offer a political programme that addressed the social issues at the core of the 1978 strike and the bread riots of 1984, although the movement did grow somewhat during this period of social tensions. What is interesting to note is that large sectors of the trade union UGTT still today have a very difficult time reconciling with Ennahda, although their ranks also include many Ennahda members and sympathizers. ${ }^{45}$

\section{Taking different paths}

From the crisis of the late 1970s and early 1980s, the movement evolved in three different directions. First, a group of liberal Islamists such as Ennafeir and el Jorchi began working for a cultural reform within Islam and subscribed to the idea of referring to a specific Tunisian Islam based on the traditional reformism of the Zitouna, which would be by its very nature closer to Tunisian society. Second, a group of radicals such as Mohammed Ali Hurath and Mohammed Khouja left and began to pursue either a dawa-inspired activism in society or armed violence. Finally, the larger group, which is usually identified with Rachid Ghannouchi and Abdelfattah Mourou, went on to form a political party in order to measure the appeal of a renewed Islamist project in a competitive political environment. It is thus that the MTI came about on 6 June 1981. What is interesting in this respect is the mechanism that drove the creation of the party and this has to do with the explicit admission that the previous theoretical categories borrowed from the experiences of the rest of the Arab world did not apply to Tunisian society, which had gone through a radically different process of socio-economic, historical, and intellectual development. Ghannouchi and Mourou recognized that one size did not fit all. As also recognized from within Ennahda today, the acceptance of the challenge of institutional politics as a mechanism to respond to the demands of the masses through categories they could easily recognize was the product of a theoretical re-elaboration that brought into Tunisian Islamism some of the concepts of the Iranian revolution. Unlike what critics of the party usually point to, the most important import from Iran is not the idea of the theocratic state, but 
the conflict between mustadaafeen (the disenfranchized) and mustaqhbareen (the arrogant). It is not so much the work of Khomeini that makes a difference for Ghannouchi and the leadership, but the analysis of Ali Shariati on class. ${ }^{46}$ They discover that the notions of disenfranchized and privileged can have a religious connotation and this is sufficient to include them in a new theoretical repositioning of the party that corresponds better to the demands of anti-Bourguiba Tunisian society for class representation in politics, particularly at a time when the left was slightly beginning to wane through the massive repression of the state and the broader loss of appeal of socialism. In the words of Ghannouchi, "the movement took a step towards society and society took a step towards the movement" because the religious connotations of the two categories of mustadaafeen and mustaqhbareen are reassuring for those conservative sectors of society that need political ideals to be embedded into religion. In addition to this, the Islamists were examining with interest the "success" of the Mestiri-led Mouvement Democratique Socialiste (MDS) as the largest opposition party in the country because it forced them to be confronted with the "liberal" idea of democratic mechanisms in so far as the MDS criticized one-party rule in the name of the inherent pluralism in Tunisian society. ${ }^{47}$ All these re-elaborations are obviously not only the direct outcome of external conditions because exclusion from society is not occurring in a vacuum: in the movement itself there was already a debate taking place about the nature of its political and social engagement through the categories of Islam. In some ways rejection serves the purpose of catalyzing debate and is at the root of the splits highlighted earlier.

This phase of exclusion continued in the early 1980s and this time it was a much more traditional form of exclusion through state repression and violence that targeted not only the radical and a small armed faction that had broken with the MTI, but also the MTI itself. Thus, the gains in society that the movement had made through the incorporation of new theoretical categories and the decision to form a political party seeking institutionalization were offset by repression. Superficially, it may appear that the repressive campaign and the imprisonment of the leadership pushed the party towards greater moderation. It is for instance in jail in the early 1980s that Rachid Ghannouchi produced the theoretical work that is now the pillar of the attitudes and policy positions of the party with respect to public freedoms in the direction of cementing democracy as the only viable political system. The repressive campaign in and of itself did not, however, directly influence the theoretical reflection and production of Ghannouchi. Such reflection for instance was not shared by all Tunisian Islamists, indicating that other Islamists equally repressed still subscribed to a different ideological framework. Nevertheless, Ghannouchi's intellectual work still constituted a significant development because it would inform and constrain the actions of militants from this point onwards, as such reflection would be increasingly discussed and eventually accepted from within. It should also be highlighted that according to Ghannouchi himself repression was a problematic interruption in what was a natural progression towards the acceptance of democratic procedures and basic 
human rights. ${ }^{48}$ In short, it is not jail that makes Islamists more moderate, but the realization that, with or without imprisonment, they had to confront a society that was still not at ease with the Manichean views that Islamists had in the 1970s and early 1980s. As Ghannouchi argues when talking to his own constituency to convince them of the necessity of a transformation within the frame of religion: "religion prospers within democracy; it is within dictatorship that it fades. Look at what happens to Muslims: they escape dictatorships in the Muslim world to look for freedom in established democracies. As Mawdudi and Qutb said, Islam is in its essence a revolution of liberation for mankind from slavery and constraints (within the limits God Imposed) ... It is both spiritual and social freedom".49

After a brief democratic opening in the late 1980s under the premiership of Mzali, who seemed to accept the commitment of the MTI to pluralism, a new repressive campaign began under then Minister of Interior Ben Ali. ${ }^{50}$ Once the latter became president in 1987 he launched a political pact that would introduce political pluralism in Tunisia and the MTI changed its name in order to take part in the construction of what they believed was going to be a new Tunisia and genuinely demonstrate its commitment to the civil nature of the state given that they dropped a clear reference to religion when the party became Ennahda. ${ }^{51}$ Ennahda was not officially recognized as a political party, but its candidates were allowed to run as independents. However a number of factors, both domestic - the better than expected results of Ennahda - and international - the civil war in Algeria - prevented the consolidation of the Tunisian process of liberalization and a new repressive campaign against Islamists began in earnest in order to avoid an Algerian scenario of violence.

Once again, this rupture is decisive for the journey of the party towards moderation because it will engender an internal debate about the necessity of building bridges with ideological rivals in opposition that were shunning Ennahda. Once again it is exclusion broadly conceived that is the explanatory mechanism. In addition to the repressive policies aimed at the annihilation of the movement, it should be underlined that the secular sector of society, represented by secular political parties and civil society groups, compounded the harsh exclusionary policies of the state against the Islamists. Secular parties and social movements were far from convinced of Ennahda's self-representation as moderate and democratic. There are solid reasons for this new social impetus against Ennahda that concerned this sector of society. First, it should be admitted that the progressive, moderate, and democratic theoretical elaborations of the leadership had a difficult time filtering down to an Islamist popular base that was incensed by repression and radicalized by international events such as the Algerian civil war or the attack against Iraq. It is clear that the process of internal change of the party towards the acceptance of democracy, women's rights, and pluralism that found its most significant expression in the signature of the national pact of 1988 had a difficult time imposing itself on the Islamist popular base. Second, the internal split within the party, symbolized in the isolation of the moderate and rather liberal co-founder Mourou, seemed to suggest that a more radical anti-systemic attitude was 
winning out internally, with an ambiguous attitude towards political violence emerging. Finally, the popular gains that the Islamist movement had made throughout the 1980s after their first rupture with their jamaa past had forced Tunisian secular parties to come to terms with the popularity of doing politics through religion. This turned them against any expression of political religiosity, whether moderate or radical, because this would fundamentally alter the secular nature of the state.

With this in mind, many secular Tunisians remained silent if not supportive of the exclusion of Ennahda throughout more than a decade. The tacit consensus for repression on the part of secular society is more significant for the second phase of theoretical re-elaboration of the party after 1991 than imprisonment or exile. For quite some time this secular fight on two fronts - against the regime and against Islamists - was a trait of most Arab societies ${ }^{52}$ but it often ended with an uneasy support for authoritarian incumbents. ${ }^{53}$ In any case, the isolation of the $1990 \mathrm{~s}$ pushed the party even more in the direction of what were quickly becoming the only internationally legitimate pillars to operate on the political scene: democracy, human rights, and the market. It was only the common destiny of repression ${ }^{54}$ that developed during the later years of the Ben Ali era between all genuine opposition players that permitted the creation of a united front against the regime that includes Ennahda. It was figures such as human rights activist and leader of the secular party Congress for the Republic Marzouki who moved first, suggesting that democracy in Tunisia would come only through an agreement with Ennahda and not against it. The progressive exclusionary repressive policies against all forms of dissent and the absence of public freedoms during the Ben Ali era pushed the party to accept at all levels the necessity of democracy and allow it to strategically form alliances with equally repressed secular political forces in the name of change. Crucial in all of this was the "final submission" to the idea that social pluralism needs to be accommodated. As Riadh Chaibi, member of the Ennahda national assembly, argued in 2011: "we are not a dogmatic party, we are a pragmatic party. We realise that Tunisia is a plural country and Europe is very close to us not only geographically. Tunisian society is similar in many ways to European societies and this is a given and we do not want to change that". ${ }^{55}$ The necessity for democracy finally found its highest coordination point in the 18 October 2005 Collectif, which can be considered the moment when Ennahda no longer faced widespread rejection from the political and social representatives of many sectors of Tunisian society; moderation is recognized as having been attained.

\section{Conclusion}

The 2011 power-sharing agreement with two centre-left parties to guide Tunisia to multi-party democracy and the recognition of the pluralism of Tunisian society seemed the obvious destination of the Islamist party Ennahda, which has moved away progressively from its anti-democratic and illiberal position to become a much more traditional religiously oriented political party. Much of the literature 
on Islamist parties that has gone through a similar transformation explains this shift over time with the moderation through inclusion thesis. This does not apply to the Tunisian case because in a strict institutional sense the Islamist movement was never genuinely afforded the possibility to participate in the political system and cross-ideological cooperation never occurred before the mid to late 2000s. Its moderation therefore needs to be accounted for differently and "moderation through exclusion" can provide an answer. The reference here is not only to the state's repression of the movement through imprisonment and exile, although this occurred on a large scale. The reference is more to a sort of societal rejection whereby the specificities of Tunisian socio-political development meant that the Islamist movement had to go through a profound re-elaboration of its initial political categories in order not to be perceived as alien and irrelevant. In particular it had to come to terms with an implicit social consensus shaped by Bourguibism and a tradition of Islamic reformism.

The Tunisian Islamist movement developed from the early 1970 s as a critical reflection of Western modernity according to the model that Bourguiba, strictly following the secular tradition of France, imposed on the country. ${ }^{56}$ This widespread and thorough critique of what was at the root of the Tunisian nationalist sentiment and ideology became progressively less central and by the late 2000 s there was an almost complete turnaround of judgement on it, which is explicit in the documents of the ninth congress of the party held in the summer of 2012. This does not imply that Bourguibism is judged positively but there is recognition that the process of construction of a moderate, nationalist, open, and Muslim Tunisia is possible because its source is a tradition of religious reformism that comes from the experience of the Zitouna and that is specifically Tunisian. The fundamentalist vision of Islam that the party had in the 1970s progressively disappeared because society rejected it and this exclusion forced the party to re-elaborate the way in which it wished to engage it. Over time the scale of rejection in society decreased and the party made significant inroads, but in order to do so it had to accept stances and attitudes that comforted the nationalist self-image of Tunisians, a "country that is both Muslim and open by virtue of its history and its geography". 57 The necessity to engage for instance with the vast politicized sectors of a unionized workforce that began to appear within the party in the late 1970s and early 1980s required the party to construct new categories of thinking and to abandon simplistic sloganeering. The realization that Tunisia has a multi-layered identity and expresses a high degree of social pluralism also affected the party and provoked an internal debate as to how better take that factor into account.

The concept of exclusion carried also a narrower connotation: state violence. There is no doubt that the experience of jail and exile had an impact on the members and activists of the party and profoundly informed the views of many of them who come into contact with leftist prisoners or with freer European societies. From a general point of view, exclusion as repression simply slowed the process of introspection that the party went through in light of societal exclusion. One of the principal characteristics of the Tunisian transition 
to democracy is that it links the political and ideological debate about the nature of the state and state-society relations to what it was in the late 1980s and even earlier to the struggle for independence. It is this inevitable mutual recognition and its institutionalization on the part of Islamists and seculars of the plural moderate Muslim nature of Tunisian society that will make or break Tunisian democratization.

\section{Acknowledgements}

The authors are thankful to the two anonymous referees for their comments, which considerably improved the article. The authors are grateful to the Gerda Henkel Foundation for funding this research in the context of the programme "From Over-estimation to Underestimation: The Trajectory of Political Islam in Five MENA Countries".

\section{Notes}

1. Churchill, "Tunisia's Electoral Lesson."

2. Hostrup Haugbølle and Cavatorta, "Beyond Ghannouchi."

3. Lynch, "Tunisia's New al-Nahda."

4. La Jeune Afrique, no. 2719, 17-23 February 2013.

5. Dahmani, "Tunisie, la laicité en danger."

6. Ozzano, "The Many Faces."

7. Hamid, "The Rise of the Islamists."

8. Clark, "The Conditions of Islamist Moderation"; Schwedler, "Can Islamists Become Moderates?"

9. For example, see the cases of Morocco since the late 1990s, Jordan since the early 1990s, Yemen since reunification and Algeria since the mid-1990s. This partly applies to Egypt as well where the Muslim Brotherhood was allowed at times to participate in controlled elections.

10. Jaffrelot, "Refining the Moderation Thesis."

11. Hafez, Why Muslims Rebel; Hamid, "The Islamist Response."

12. Roy, "Les Islamistes."

13. Stepan, "Tunisia's Transition."

14. See for instance the interview with Mohammed Talbi, "Ennahda est un cancer."

15. Masoud, "Are they Democrats?"

16. Allani, "The Islamists in Tunisia."

17. Tamimi, Rachid Ghannouchi.

18. Rachid Ghannouchi is the current president of the party and its long-time leader. He was among the founding members and he is also recognized for his scholarly work on the relationship between Islam and democracy.

19. For a discussion on this issue see Kramer, "Islamist Notions."

20. Hostrup Haugbølle and Cavatorta, "Will the Real Tunisian Opposition Please Stand Up?"

21. Interview with authors, Tunis, October 2011.

22. Torelli, Merone, and Cavatorta, "Salafism in Tunisia."

23. Authors' interview with Rachid Ghannouchi, 30 October 2012.

24. Kausch, "Islamist-led Foreign Policies."

25. Merone and Cavatorta, "Salafist Mouvance and Sheikh-ism."

26. For a discussion of the relations between the West and Tunisia under Ben Ali, see Durac and Cavatorta, "Strengthening Authoritarian Rule." 
27. See, for instance, Mortimer, "Islamists, Soldiers and Democrats."

28. Browers, Political Ideology; Cavatorta, "Civil Society."

29. Browers, "Origins and Architects"; Clark, "Threats, Structures and Resources"; Abdelrahman, "With the Islamists?"

30. Roy, The Failure of Political Islam.

31. Schwedler, Faith in Moderation.

32. Clark, "The Conditions of Islamist Moderation."

33. Wegner and Pellicer, "Left-Islamist Opposition Cooperation"; Ryan, "Political Opposition."

34. Gurses, "Islamists, Democracy and Turkey"; Wegner, Islamist Opposition.

35. Karakaya and Yildirim, "Islamist Moderation."

36. Hafez, "From Marginalisation to Massacres"; Hafez, Why Muslims Rebel; Hamid, "The Islamist Response."

37. Torelli, "The 'AKP Model'."

38. Alexander, Tunisia.

39. Interview with authors, Tunis, 30 October 2012.

40. Interview with authors, Tunis, 29 October 2012.

41. Interview with Aymen Brayek, Ennahda student coordinator at Zitouna University, Tunis, 31 October 2012.

42. Authors' interview with Rachid Ghannouchi, 30 October 2012.

43. Ibid.

44. On the relationship between workers and Islamists see Alexander, "Opportunities, Organization and Ideas."

45. Yousfi, "Ce syndicat."

46. Authors' interview with Rachid Ghannouchi, 30 October 2012.

47. Penner Angrist, "Parties, Parliament."

48. Interview with authors, Tunis, 30 October 2012.

49. Rachid Ghannouchi, interview in Arabic with Al Jazeera in the context of the programme "Sharia and Life." Posted on 5 February 2012 and available on YouTube at: http://www.youtube.com/watch?v=mWLkfAR6xiY.

50. Murphy, Economic and Political Change in Tunisia.

51. Anderson, "Political Pacts."

52. Ottaway and Hamzawy, "Fighting on Two Fronts."

53. Cook, "The Right Way"; Kraetzschmar, "Mapping Opposition Cooperation in the Arab World."

54. Beau and Tuquoi, Notre Ami.

55. Interview with authors, Tunis, October 2011.

56. Alexander, Tunisia.

57. Authors' interview with Rachid Ghannouchi, 30 October 2012.

\section{Notes on contributors}

Francesco Cavatorta is a senior lecturer in the School of Law and Government at Dublin City University, Dublin, Ireland. He will join the Department of Political Science at Universite Laval, Quebec, Canada, in August 2013. His current research focuses on Islamist parties and movements in North Africa.

Fabio Merone is a research assistant on the project "From Over-estimation to Under-estimation: The Trajectory of Political Islam in Five MENA Countries", Gerda Henkel Foundation. He is based in Tunis and his research focuses on Islamist parties and movements in North Africa. 


\section{Bibliography}

Abdelrahman, M. "With the Islamists? - Sometimes. With the State? - Never! Cooperation between the Left and Islamists in Egypt." British Journal of Middle Eastern Studies 36, no. 1 (2009): 37-54.

Alexander, C. "Opportunities, Organization and Ideas: Islamists and Workers in Tunisia and Algeria." International Journal of Middle East Studies 32, no. 4 (2000): 465-490.

Alexander, C. Tunisia. Stability and Reform in the Modern Maghreb. London: Routledge, 2010.

Allani, A. "The Islamists in Tunisia between Confrontation and Participation: 1980-2008." Journal of North African Studies 14, no. 2 (2009): 257-272.

Anderson, L. "Political Pacts, Liberalism and Democracy: The Tunisian National Pact of 1988." Government and Opposition 26, no. 2 (1991): 244-260.

Beau, N., and J.-P. Tuquoi. Notre Ami Ben Ali. Paris: La Découverte, 1999.

Browers, M. "Origins and Architects of Yemen's Joint Meeting Press." International Journal of Middle East Studies 39, no. 4 (2007): 565-586.

Browers, M. Political Ideology in the Arab World. Cambridge: Cambridge University Press, 2009.

Cavatorta, F. "Civil Society, Islamism and Democratisation. The Case of Morocco." Journal of Modern African Studies 44, no. 2 (2006): 203-222.

Churchill, E. "Tunisia's Electoral Lesson: The Importance of Campaign Strategy." Sada, October 27, 2011. http://carnegieendowment.org/2011/10/27/tunisia-s-electoral-lessonimportance-of-campaign-strategy/fbjo

Clark, J. "The Conditions of Islamist Moderation: Unpacking Cross-Ideological Cooperation in Jordan." International Journal of Middle East Studies 38, no. 4 (2006): 539-560.

Clark, J. "Threats, Structures and Resources." Comparative Politics 43, no. 3 (2010): 101-120.

Cook, S. "The Right Way to Promote Arab Democracy." Foreign Affairs 84, no. 2 (2005): 91-102.

Dahmani, F. “Tunisie, la laïcité en danger. ” La Jeune Afrique no. 2623/2634, April 17-30, 2011, 36-37.

Durac, V., and F. Cavatorta. "Strengthening Authoritarian Rule Through Democracy Promotion? Examining the Paradox of the US and EU Security Strategies. The Case of Tunisia." British Journal of Middle Eastern Studies 36, no. 1 (2009): 3-19.

Gurses, M. "Islamists, Democracy and Turkey: A Test of the Inclusion-Moderation Hypothesis." Party Politics (2012): 1-14. doi: 10.1177/1354068812448688

Hafez, M. Why Muslims Rebel. Repression and Resistance in the Islamic World. Boulder, CO: Lynne Rienner, 2003.

Hafez, M. "From Marginalisation to Massacres: A Political Process Explanation of GIA Violence in Algeria." In Islamic Activism, edited by Quintan Wiktoriwicz, 37-60. Bloomington: Indiana University Press, 2004.

Hamid, S. "The Islamist Response to Repression." Policy Briefing, Doha Brookings Institute, August 2010, 1-25.

Hamid, S. "The Rise of the Islamists." Foreign Affairs 90, no. 5 (2011): 40-47.

Hostrup Haugbølle, R., and F. Cavatorta. "Will the Real Tunisian Opposition Please Stand Up?! Opposition Coordination Failures Under Authoritarian Constraints." British Journal of Middle Eastern Studies 38, no. 3 (2011): 323-341.

Hostrup Haugbølle, R., and F. Cavatorta. "Beyond Ghannouchi. Islamism and Social Change in Tunisia." Middle East Report 262 (2012): 20-25.

Jaffrelot, Christophe. "Refining the Moderation Thesis. Two Religious Parties and Indian Democracy: The Jana Sangh and the BJP between Hindutva Radicalism and Coalition Politics." Democratization 20, no. 5 (2013): 876-894. 
Kausch, Kristina. "Islamist-led Foreign Policies: What Implications?", Fride Policy Brief no. 120, March 2012, 1-6.

Karakaya, S., and K. Yildirim. "Islamist Moderation in Perspective: Comparative Analysis of the Moderation of Islamist Parties and Western Communist Parties." Democratization (2012): 1-28.

Kraetzschmar, H. "Mapping Opposition Cooperation in the Arab World: From Single-Issue Coalitions to Transnational Networks." British Journal of Middle Eastern Studies 38, no. 3 (2011): 287-302.

Kramer, G. "Islamist Notions of Democracy." Middle East Report no. 183 (1993). http:// www.merip.org/mer/mer183/islamist-notions-democracy

Lynch, M. "Tunisia's New al-Nahda." Foreign Policy, June 29, 2011. http://lynch. foreignpolicy.com/posts/2011/06/29/tunisias_new_al_nahda

Masoud, T. "Are they Democrats? Does it Matter?" Journal of Democracy 19, no. 3 (2008): $19-24$.

Merone, F., and F. Cavatorta. "Salafist Mouvance and Sheikh-ism in the Tunisian Transition." Center for International Studies, Working Paper no. 7, 2012. http://doras. dcu.ie/17570/1/1207.pdf

Mortimer, R. "Islamists, Soldiers and Democrats: The Second Algerian War." Middle East Journal 50, no. 1 (1996): 18-39.

Murphy, E. C. Economic and Political Change in Tunisia: From Bourguiba to Ben Ali. London: Macmillan Press, 1999.

Ottaway, M., and A. Hamzawy. "Fighting on Two Fronts. Secular Parties in the Arab World." Carnegie Papers 85, 2007, 1-25. http://carnegieendowment.org/files/cp85 secular final.pdf

Ozzano, Luca, "The Many Faces of the Political God: A Typology of Religiously Oriented Parties." Democratization 20, no. 5 (2013): 807-830.

Penner Angrist, M. "Parties, Parliament and Political Dissent in Tunisia." Journal of North African Studies 4, no. 4 (1999): 89-104.

Roy, O. "Les Islamistes ne sont pas de démocrates." Realités, no. 1401, November 20121 $7,52-56$.

Roy, R. The Failure of Political Islam. London: I. B. Tauris, 1994.

Ryan, C. "Political Opposition and Reform Coalitions in Jordan." British Journal of Middle Eastern Studies 38, no. 3 (2011): 367-390.

Schwedler, J. "Can Islamists Become Moderates? Rethinking the Inclusion-Moderation Hypothesis." World Politics 63, no. 2 (2011): 347-376.

Schwedler, J. Faith in Moderation. Cambridge: Cambridge University Press, 2006.

Stepan, A. "Tunisia's Transition and the Twin Tolerations." Journal of Democracy 23, no. 2 (2012): 89-103.

Talbi, M. "Ennahda est un cancer." Jeune Afrique, no. 2703/2704, October 28-November $10,2012,50-53$.

Tamimi, A. Rachid Ghannouchi: A Democrat within Islamism. Oxford: Oxford University Press, 2001.

Torelli, S. "The "AKP Model' and Tunisia's al-Nahda: From Convergence to Competition?" Insight Turkey 14, no. 3 (2012): 65-83.

Torelli, S., F. Merone, and F. Cavatorta. "Salafism in Tunisia: Challenges and Opportunities for Democratization." Middle East Policy 19 (2012): 140-154.

Wegner, E. Islamist Opposition in Authoritarian Regimes. The Party of Justice and Development in Morocco. Syracuse, NY: Syracuse University Press, 2011.

Wegner, E., and M. Pellicer. "Left-Islamist Opposition Cooperation in Morocco." British Journal of Middle Eastern Studies 38, no. 3 (2011): 303-322.

Yousfi, H. "Ce syndicat qui incarne l'opposition tunisienne." Le Monde Diplomatique no. 704 (November 2012): 17-18. 